109.

$612.563: 615 \cdot 75: 615 \cdot 785$

皮䖉罝度二關スル藥理學的研究

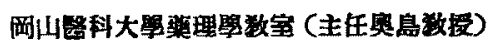

学士 小泉 三 郎

[昭和 13 年 3 月 12 日受栜]

Aus dem Pharmakologischen Instifut der Medizinischen Fakultät Okayama.

(Vorstand: Prof. Dr. K. Okwshima)

Pharmakologische Studien über die Hauttemperatur.

Von

Dr. Saburo Koizumi.

Eingegangen am 12. März 1938.

Verfasser untersuchte mit einem Messapparat für Hauttemperatur, „Mikro-pyrometer, Eko" den Einfluss einiger Antipyretika, vegetativer Nervengifte und Krampfgifte auf die Hauttemperatur des Kaninchens, indem er die Muskel- und Korpertemperatur, die bei demselben Kaninchen zur gleichen Zeit gemessen wurden, vergleichend beobachtete. Daneben wurden auch die Veränderung dieser Temperatur infolge von physiologischen und experimentellen Bedingungen beobachtet. Die Hauttemperatur wurde am Wurzel der Ohrlappen und an der Rückenhaut gemessen. Als Antipyretika wurden Antipyrin, Chinin, Natrium-salicylat, Neopirin (Aspirium solubile), als vegetative Nervengifte Adrenalin, Atropin, Pilocarpin und Acetylcholin und als Krampfgifte Pikrotoxin und Strychnin benutzt. Die Ergebnisse der Experimente lassen sich wie folgt kurz zusammenfassen :

1) Wird das Kaninchen in der Bauchlage fest gebunden, so sinkt Korper-, Muskelund Hauttemperatur und hält nach 1-1.5 Stunden lange Zeit eine ziemlich bestimmte Hohe. Wenn jedoch das Tier während der Experimente zu krampfartigen Bewegungen kommt, so steigern sich diese Temperaturen vorübergehend.

2) Der Einfluss der Korpertemperatur auf die Hauttemperatur ist je nach der Hautgegend sehr verschieden. Die Temperatur der Rückenhaut wird auffallend durch die Korpertemperatur (in der Bauchhohle gemessen) beeinflusst, dagegen wird die 
Hauttemperatur der Ohrlappen duroh die Temperatur der Aussenwelt viel mehr als durch die Korpertemperatur bestimmt. Die Muskeltemperatur kommt der Korpertemperatur am năchsten.

3) Wenn man die Hauttemperatur an Wurzelteil der Ohrlappen unter der Wirkung verschiedener Gifte beobachtet, so ninmt sie oft einen gegensātzlichen Verlauf zur Korpertemperatur, d. h. Antipyrin, Chinin und Natrium-salicylat steigern in vielen Fällen die Hauttemperatur; besonders auffallend ist das bei Antipyrin der Fall. Dagegen wirkt Adrenalin auf die Heuttemperatur erniedrigend. Atropin und Neopirin üben keine Veränderung aus. Pilocarpin und Acetylcholin haben eine Neigung zur Erhohung. Pikrotoxin zeigt gar keinen Einflues, aber beim Pikrotoxinkrampf tritt eine vorübergehende Temperatursteigerung auf. Bei Strychnin erfolgt ein geringer $\mathbf{A b s t i e g ,}$ jedoch tritt beim Strychninkrampf dieselbe Erscheinung auf, wie beim Pikrotoxinkrampf.

4) Der Mechanismus der Wirkung dieser Gifte auf die Hauttemperatur erscheint zum Teil von der Vermehrung oder Verminderung der in den Hautgefăssen stromenden Blutmenge abhängig zu sein. Infolge der durch die gennanten Substanzen hervorgerufenen Erweiterung oder Kontraktion der peripheren Gefässe ist die Menge des Blntes hier groseer oder kleiner. Ausserdem würde die steigernde Wirkung der oben erwăhnten Antipyretika auf die Hauttemperatur anf ihrer Wirkung auf die Gefässzentren beruhen. In allen Fällen aber würde die Verănderung der Korpertemperatur in einem gewissen Grad auf die Hauttemperatur beeinflussen, sodass die letztere sozusagen durch das arithmetische Mittel aller gennanten Faktoren bestimmt wird.

(Autoriferat)

\section{棈 专}

皮成溫度二關シテハ古來ヨリ諾家ニヨリ丁

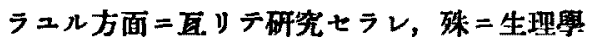

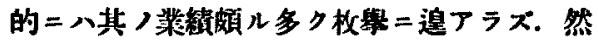
レド愁理祭的二八皮成溫度=關ス几研究報

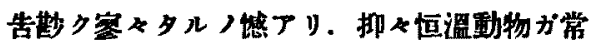

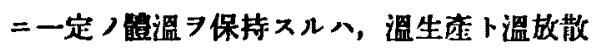
ヨ調䇠スルニ依ルモノニシテ, 溫放散八呼吸

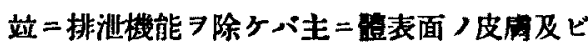
粘膜ニョルモノナリ，依りテ體溫調節=際シ テ皮属㯰度つ變化スル八勿論ナリ．然レドモ
皮椆賉度 7 考察スル ナル保件ニヨリ決定スルカラ考フル＝1）能 內縕織內二於ヶ儿溫熱／發生，2）低溫又一

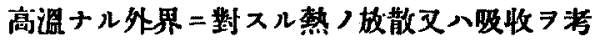

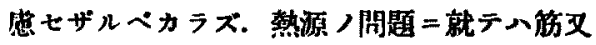

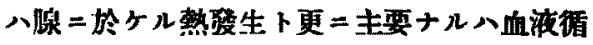

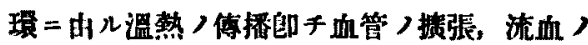
速度均加等考一得べク，外界二對ス儿熱つ故 散八外策，溫度，空氣 /流動, 孯度站=光秋

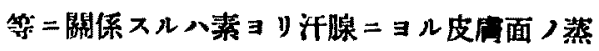

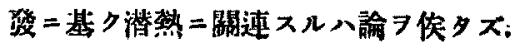

13. 


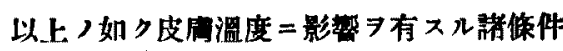

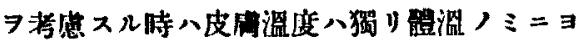

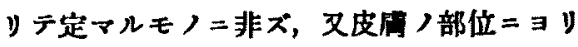
テモ美異フルモノナラン・サレバ䊾物ノ作用

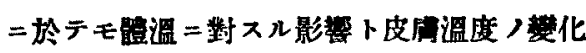
トハ必ズシモー玫セザルコトアルベキハ容易 二想像シ得ル所ナリ．是レ余方本研究 7 企テ タル所以ナリ．菜理藇上皮成㯰度二關ス几研

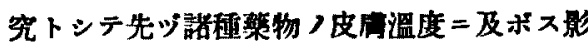
帮フ檢スルニ虽り溫熱卜最モ關係アル解熱䘞

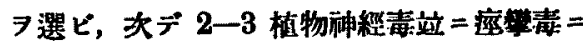
就キ實驗セリ，解熱剂トシテハ平生臨林上常 二用ヒラルモノフ選ビ，Antipgrin岛トシテ Antipyrin 7 , Chinin hydrochloricum $7, 「 ロ イ マ チ ス 」$ 策 (Antirheumatica）ナルモ屡ね解熱敖トシテ適用 Łラル Natrium salicylicum 及ピ Aspirin (Acidum acetylsalicylicum) , 代 $y=$ Neopirin (Calcium acetylsalicylieum, Aspirinum solubile) $\ni$ ，植物神經毒トシテハ Adrenalin, Atropin, Pilocarpin, Acetylcholin 7 ，座㢣毒トシテハ Strychnin, Pikrotoxin ヨ選ビタリ.

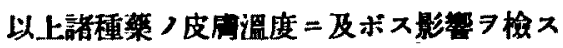

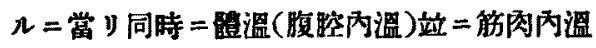
モ测定シテ此较研究シ，份木之等㯰度 生 理的狀態=於ケル變化 モモ併七テ詳細ニ檢シ 3ㅂ:

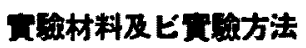

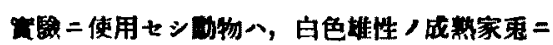

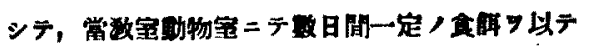

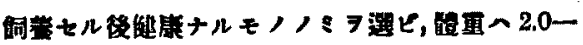

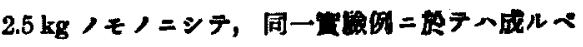

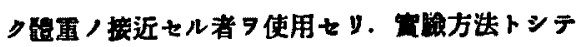
一溫度湘定二八皮闻溫度澌定器 Micro-yyrometer

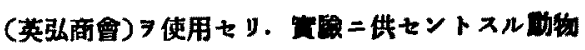

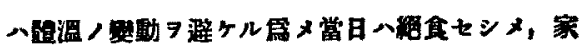

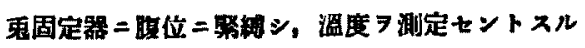

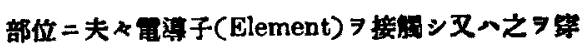

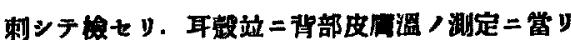

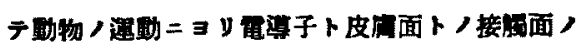

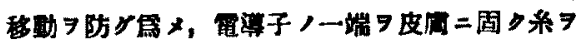

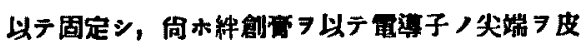

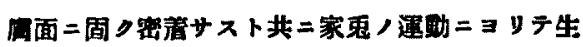

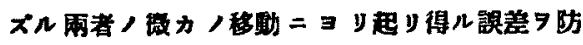

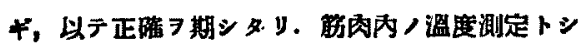

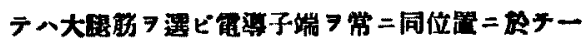

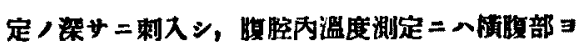

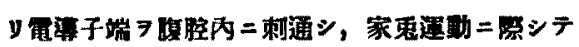

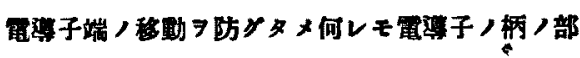

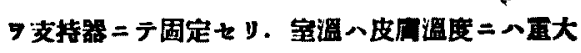

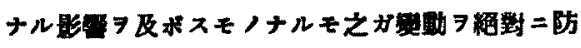

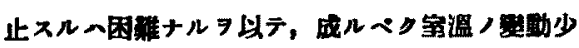

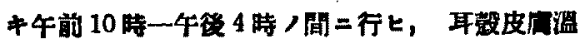

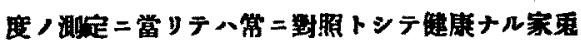

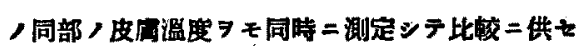

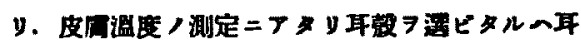

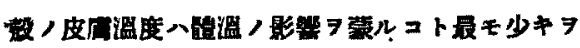
上テ最遒ナリト思考シタレバナリ．聚物八漶テ皮

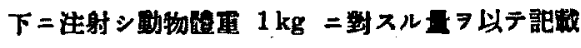
七y.

\section{霓醶成維}

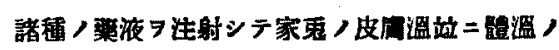

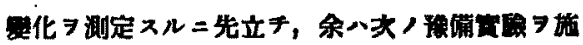


行セり.

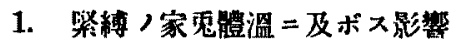

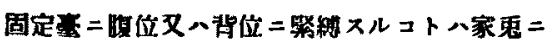

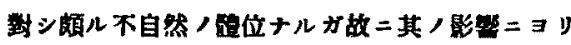

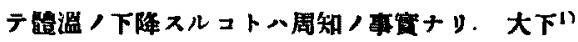

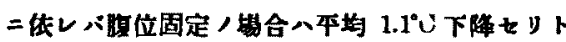
謂七，阿部”，背位固定，時八平均約 $20 \mathrm{C}$ ，下降

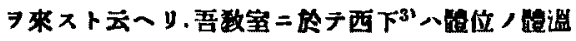

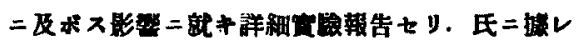

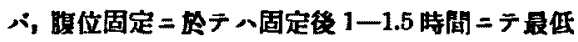
温度二莲シ本均 0.790 人下降

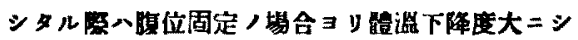
テ固定得 1-1.5 時間ニシテ本均 $1.63^{\circ} \mathrm{C} 7$ 示シ, 其

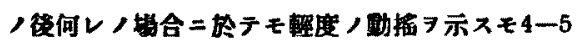

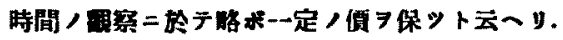

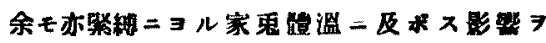
Micro-pyrometer $=\Xi$ リ䐓腔内温度 7 娘シタル

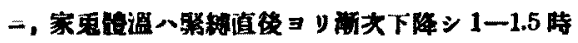

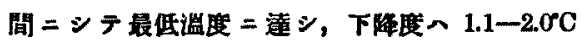
ニシテ平均 $1.4^{\circ} \mathrm{C}$ ，佰习得タy. 而シテ Micro-

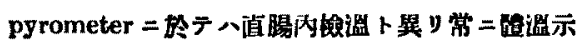

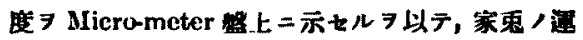

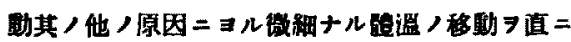

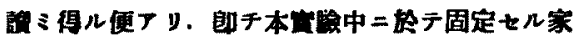

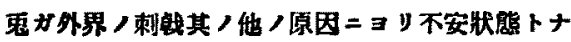

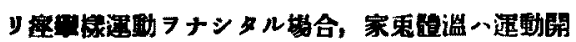

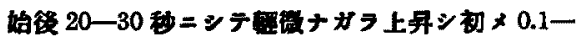

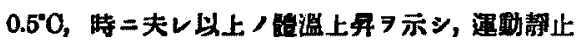

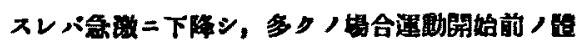

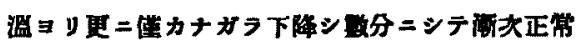

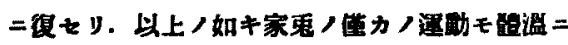
著シキ象化 7 及标ス 7 以テ, Micro-pyrometer =

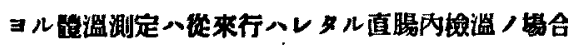
二於ケルカ如キ家鬼 $习$ 保持シタy，其八他八国影

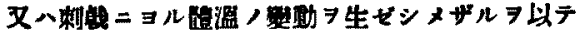

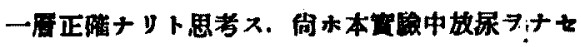

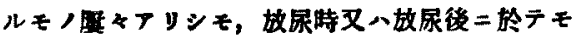

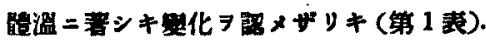

2. 緊縛ノ家鬼皮席端二称溫二及ボス影 䓛

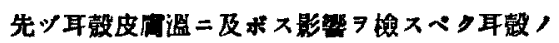

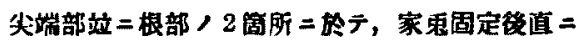

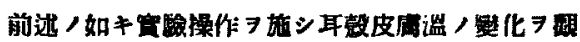

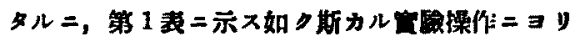

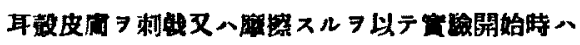

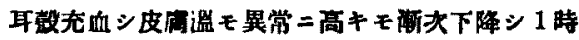

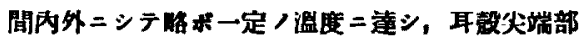

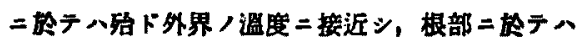

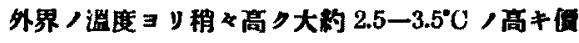
ヨ示ス. 其 /

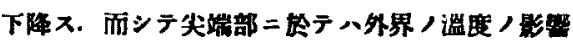
大ナル

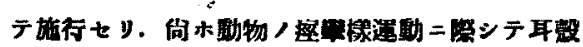

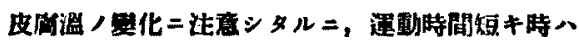

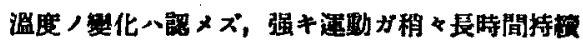

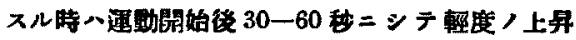

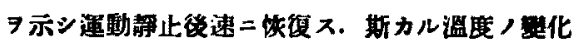

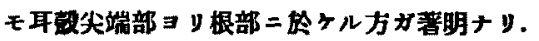

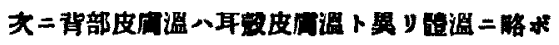
近化カ=3-4.

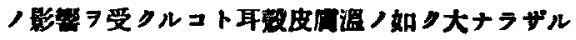
ヨ以テ，祭轴 = シ本均 $1.2 \mathrm{C}$ ノ下降 澄 ノ野

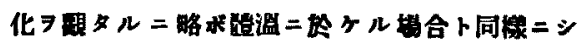
テ，固定後 1-1.5 㭙間=シテ传低谓度二連シ 0.8

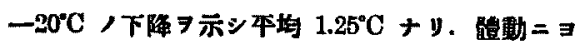

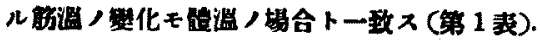


第 1 表

\begin{tabular}{|c|c|c|c|c|c|c|c|}
\hline \multirow[t]{3}{*}{ 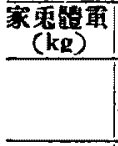 } & \multicolumn{4}{|c|}{2220} & \multicolumn{3}{|c|}{2150} \\
\hline & 耳 敦 & 成 温 & 量 潜 & 温 & 背部皮溫 & 温 & 室 \\
\hline & 根 部 & 端部 & & & & & \\
\hline 固定時 & 28.7 & 26.4 & 38.8 & 20.5 & 35.4 & 37.5 & 21.2 \\
\hline $5^{\prime}$ & 28.2 & 26.1 & & $" \prime$ & $" n$ & & \\
\hline $10^{\prime}$ & 27.6 & 25.5 & & " & 35.3 & & \\
\hline $15^{\prime}$ & 26.8 & 24.2 & 38.5 & 20.7 & 35.2 & 37.3 & 21.4 \\
\hline $2 \theta^{\prime}$ & 26.0 & 23.3 & & 20.6 & 35.0 & & \\
\hline $25^{\prime}$ & 25.6 & $" \prime$ & & & $" \prime$ & & \\
\hline $29^{\prime}$ & 25.1 & 23.2 & & 20.8 & & & \\
\hline 霜 $30^{\prime}$ & 26.0 & 23.4 & 38.1 & $"$ & 34.8 & 37.0 & 21.7 \\
\hline$n \backslash 31^{\prime}$ & 25.4 & 23.1 & & $n$ & & & \\
\hline $40^{\prime}$ & 25.0 & 22.8 & $\rightarrow+\infty$ & 21.0 & 34.7 & & \\
\hline $50^{\prime}$ & 24.8 & 22.4 & 20 & 21.2 & $" \prime$ & & \\
\hline $1^{\circ} 00^{\prime}$ & $"$ & 22.0 & 37.7 & $n$ & 34.6 & 36.4 & 21.9 \\
\hline $10^{\prime}$ & 24.6 & $"$ & & 21.3 & 34.5 & & \\
\hline $20^{\prime}$ & 24.5 & 22.1 & & $\|$ & 34.3 & & \\
\hline $30^{\prime}$ & $"$ & $"$ & 37.5 & 21.5 & $" \prime$ & 36.2 & 22.0 \\
\hline $40^{\prime}$ & 24.4 & 22.2 & & 21.6 & $" \prime$ & & \\
\hline $50^{\circ}$ & $"$ & $\cdot " \prime$ & & 21.8 & 34.4 & & \\
\hline $2^{\circ} 00^{\prime}$ & 24.5 & 22.3 & 37.5 & $u$ & $"$ & 36.3 & 22.0 \\
\hline
\end{tabular}

3. 2-3 解熱刦/皮膚溫二及ボス影策

1) Antipyrin

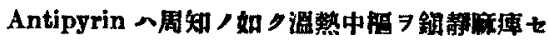

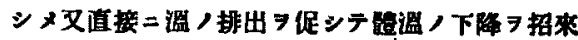

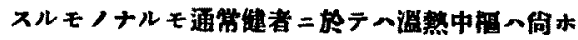
完全ナル調温㙨能

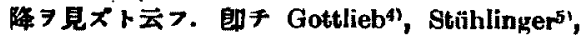

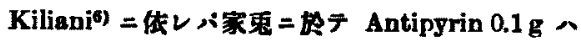

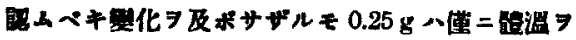

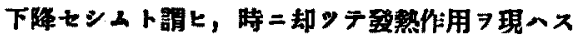

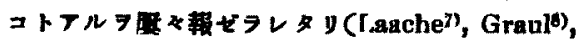
Fröhner"), Jiepelt(10), Barbour u. Deming ${ }^{11)}$. 又

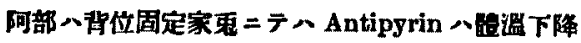
作用习星をズト云七，西下二訨レパ Antipyrin ハ

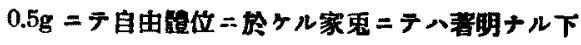

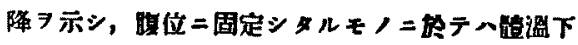
降茜タ微弱ニシテ，背位二固定シタルモノニ领テ

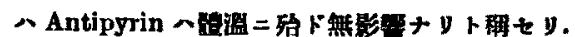

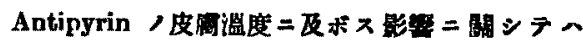

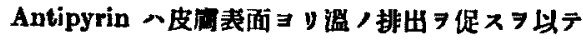

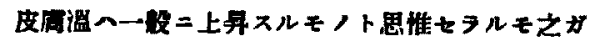

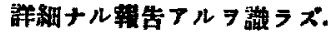

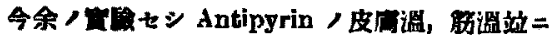

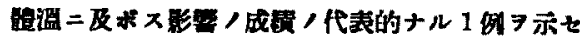

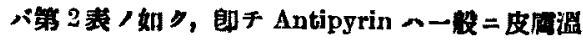
度习.上年セシムルモノ/如りAntipyrin注射家鬼

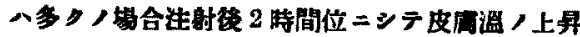

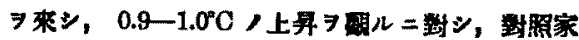

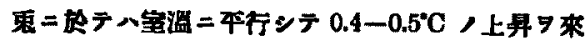

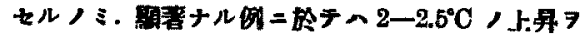

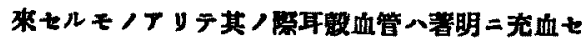

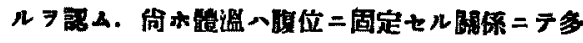

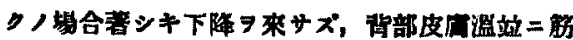

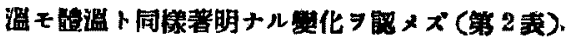


第 2 裴

\begin{tabular}{|c|c|c|c|c|c|c|c|}
\hline \multirow[t]{2}{*}{ 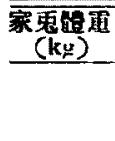 } & \multicolumn{4}{|c|}{2380} & \multicolumn{3}{|c|}{2230} \\
\hline & 耳款皮的温 & 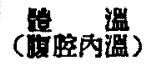 & 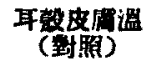 & 害 嘼 & 背部皮压昷 & 第 滥 & 湿 \\
\hline 固定時 & 27.2 & 39.1 & 28.5 & 18.7 & 35.1 & 37.5 & 19.0 \\
\hline $30^{\prime}$ & 25.0 & 38.5 & 25.4 & & 34.5 & 36.8 & \\
\hline $1^{\circ} 00^{\prime}$ & 23.3 & 38.1 & 24.1 & 19.2 & 34.2 & 36.1 & 19.4 \\
\hline $30^{\prime}$ & 23.0 & 37.8 & 22.9 & & 33.9 & 35.6 & \\
\hline $2^{\circ} 00^{\prime}$ & 23.1 & 37.7 & 22.9 & 19.9 & 34.0 & 35.5 & 20.1 \\
\hline \multicolumn{5}{|c|}{ Antipyrin $0.5 \mathrm{~g}$} & \multicolumn{2}{|c|}{ Antipyrin $0.5 \mathrm{~g}$} & \\
\hline $20^{\prime}$ & 23.2 & 37.6 & 23.0 & 20.0 & 34.0 & 35.5 & 20.2 \\
\hline $40^{\prime}$ & 23.3 & $"$ & 23.1 & 20.1 & & & \\
\hline $1^{*} 00^{\prime}$ & 23.4 & 37.7 & 23.2 & 20.2 & 34.1 & 35.6 & 20.4 \\
\hline $20^{\prime}$ & 23.5 & 37.6 & $"$ & 20.3 & & & \\
\hline $40^{\prime}$ & 23.7 & $" \prime$ & 23.3 & 20.4 & & & \\
\hline $2^{\circ} 00^{\prime}$ & 24.0 & 37.5 & 23.4 & $" l$ & 34.0 & 35.4 & 20.6 \\
\hline $20^{\prime}$ & 24.2 & 37.4 & 23.5 & 20.6 & & & \\
\hline $40^{\prime}$ & 23.9 & $"$ & $"$ & & & & \\
\hline $3^{\circ} 00^{\prime}$ & 23.8 & 37.5 & 23.4 & 20.5 & 83.9 & 35.3 & 20.9 \\
\hline $20^{\prime}$ & $" \prime$ & $"$ & 23.5 & 20.6 & & & \\
\hline $40^{\prime}$ & 23.7 & 37.6 & 23.3 & 20.4 & & & \\
\hline $4^{\circ} 00^{\prime}$ & $-3, f j$ & $"$ & $"$ & 20.3 & 34.0 & 35.4 & 31.3 \\
\hline
\end{tabular}

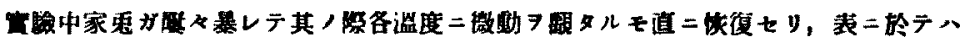
そガ記載・略セリ．以下ノ表二於テモ同ジ.

2) Chininum hydrochloricum

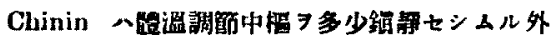

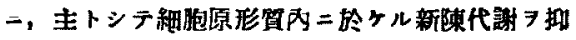

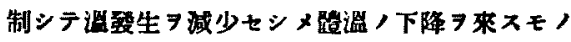

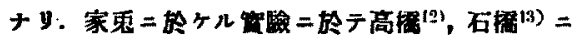

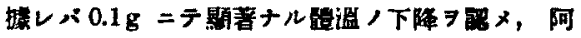

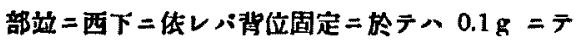
$0.35-0.4^{\circ} \mathrm{C}, 0.2 \mathrm{~g}=$ テ $0.8-1.5^{\circ} \mathrm{C}$ 人能温下降 7

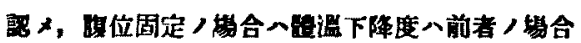

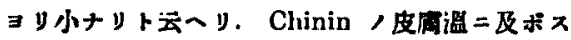

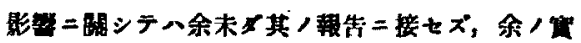
卧セシ成㯰 7 代表的二 1 例 7 表示スレハ，第 3 表

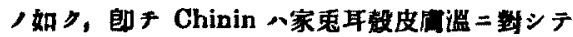

Antipyrin 卜同橉拄射挠 1.5一2時間二シテ多タハ

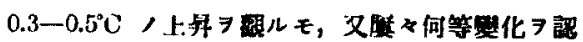

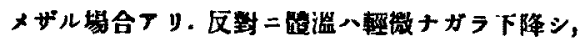

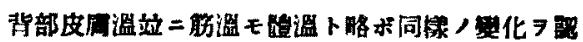
A (第 3 表).

3) Natrium salicylicum

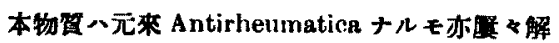

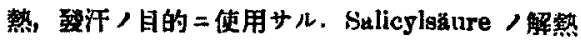

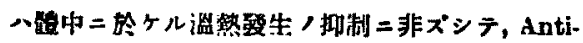
pyrin，如澄排出，增大= ムモノト云ハレ，解熱特二八血管㗅大シ甚タシキ 登汗

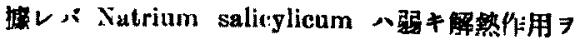


第 3 表

\begin{tabular}{|c|c|c|c|c|c|c|c|}
\hline \multirow[t]{2}{*}{$\begin{array}{c}\text { 家鬼铻重 } \\
\text { (kg) }\end{array}$} & \multicolumn{4}{|c|}{2290} & \multicolumn{3}{|c|}{2170} \\
\hline & 耳㰻皮用诋 & 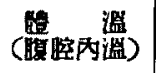 & $\begin{array}{c}\text { 耳瑴皮温 } \\
\text { (對盟) }\end{array}$ & 宝秏 & 背部皮虐罚 & 觔 罝 & 温 \\
\hline 固定時 & 26.5 & 38.9 & 27.1 & 20.5 & 36.3 & 37.3 & 20.5 \\
\hline 後 $30^{\prime}$ & 25.1 & 38.1 & 25.4 & & 36.0 & 36.5 & \\
\hline $1^{*} 00^{\prime}$ & 24.0 & 37.5 & 24.2 & 20.6 & 35.7 & 36.2 & 20.7 \\
\hline $30^{\prime}$ & 23.4 & 37.6 & 23.5 & & 35.2 & 36.0 & \\
\hline $2^{\circ} 00^{\prime}$ & 23.6 & 37.4 & 23.7 & 21.0 & 35.1 & $\downarrow^{36.2}$ & 20.9 \\
\hline 注射後 & \multicolumn{2}{|c|}{ Chinin $0.1 \mathrm{~g}$} & & & \multicolumn{2}{|c|}{ Chinin $0.1 \mathrm{~g}$} & \\
\hline $20^{\prime}$ & 23.6 & 37.4 & 23.8 & 21.1 & 35.1 & 36.2 & 21.1 \\
\hline $40^{\prime}$ & 23.8 & $" \prime$ & 23.9 & 21.2 & & & \\
\hline $1^{\circ} 00^{\prime}$ & 23.9 & 37.3 & 24.0 & 21.3 & 35.0 & 36.1 & 21.3 \\
\hline $20^{\prime}$ & 24.1 & 37.2 & $" \prime$ & $" \prime$ & & & \\
\hline $40^{\prime}$ & 24.4 & $"$ & 24.1 & 21.4 & & & \\
\hline $2^{\circ} 00^{\prime}$ & $"$ & 37.1 & 24.2 & 21.5 & 34.8 & 35.8 & 21.4 \\
\hline $20^{\prime}$ & 24.3 & 37.2 & $" \prime$ & $"$ & & & \\
\hline $40^{\prime}$ & 24.4 & 37.1 & $" \prime$ & 21.4 & ' & & \\
\hline $3^{\circ} 00^{\prime}$ & 24.3 & 37.0 & 24.1 & $"$ & 34.7 & 35.7 & 21.2 \\
\hline $30^{\prime}$ & 24.2 & 37.1 & 24.0 & 21.3 & & & \\
\hline $4^{\circ} 00^{\prime}$ & $"$ & $" \prime$ & $"$ & $"$ & 34.8 & 35.6 & 21.1 \\
\hline
\end{tabular}

第 4 表

\begin{tabular}{|c|c|c|c|c|c|c|c|c|}
\hline \multirow[t]{2}{*}{ 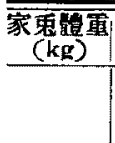 } & \multicolumn{4}{|c|}{2410} & \multicolumn{4}{|c|}{2390} \\
\hline & 耳款皮酒温 & 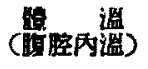 & 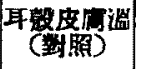 & 室＼cjkstart㵋 & 耳款皮屚滥 & 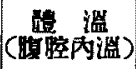 & 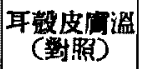 & 室 溫 \\
\hline 固定時 & 27.8 & 38.8 & 26.7 & 19.5 & 26.1 & 39.2 & 26.7 & 20.1 \\
\hline 後 $30^{\prime}$ & 24.9 & 38.4 & 24.8 & & 24.8 & 38.1 & 25.0 & \\
\hline $1^{\circ} 00^{\prime}$ & 23.5 & 38.0 & 24.1 & 19.8 & 23.1 & 37.9 & 23.3 & 20.4 \\
\hline $30^{\prime}$ & 23.2 & 37.7 & 22.9 & & 22.2 & 37.7 & 22.5 & \\
\hline $2^{\circ} 00^{\prime}$ & $23.0 \downarrow$ & 37.6 & 22.8 & 20.1 & $22.4+$ & 37.9 & 22.6 & 20.6 \\
\hline 注射嵝 & Natr. & icyl. $0.5 \mathrm{~g}$ & & & Neopir & $\operatorname{rin} 0.3 \mathrm{~g}$ & & \\
\hline $20^{\prime}$ & 23.0 & 37.8 & 22.9 & 20.2 & 22.4 & 37.9 & 22.7 & 20.7 \\
\hline $40^{\prime}$ & 23.1 & $" \prime$ & $" \prime$ & 20.3 & 22.3 & . & 22.8 & \\
\hline $1^{\circ} 00^{\prime}$ & 23.3 & 37.5 & 23.0 & 20.4 & 22.6 & 37.8 & 22.9 & 20.8 \\
\hline $20^{\prime}$ & 23.4 & $"$ & 23.2 & 20.5 & 22.7 & & $\prime \prime$ & $"$ \\
\hline $40^{\prime}$ & 23.7 & 37.4 & 23.4 & 20.7 & 22.6 & . & 23.0 & 20.9 \\
\hline $2^{\circ} 00^{\prime}$ & 24.0 & 37.5 & 23.6 & 20.9 & 22.8 & 37.7 & 23,1 & 21.2 \\
\hline $20^{\prime}$ & $"$ & $"$ & $"$ & $"$ & 23.0 & & 23.2 & 21.2 \\
\hline $40^{\prime}$ & 23.9 & 37.6 & 23.5 & 20.8 & $\|$ & & $"$ & 21.3 \\
\hline $3^{\circ} 00^{\prime}$ & $2\} .1$ & $"$ & 23.6 & 21.0 & 23.2 & 37.8 & 23.4 & $21.5^{i}$ \\
\hline $30^{\prime}$ & 24.0 & 37.5 & 23.5 & $" \prime$ & 23.1 & $\therefore$ & 23.3 & 21.3 \\
\hline 100 & 23.8 & 37.4 & 23.5 & 20.8 & 22.9 & 37.7 & 23.2 & 21,1 \\
\hline
\end{tabular}




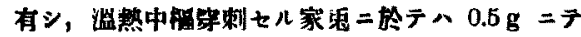

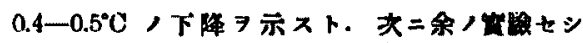

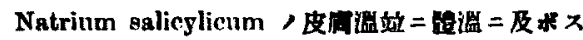

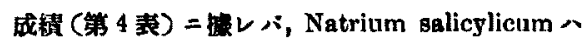

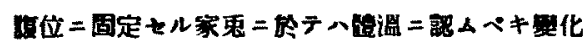

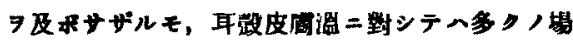

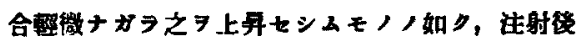

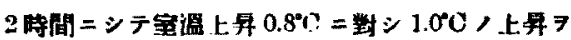

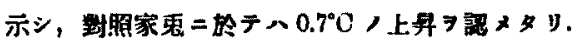

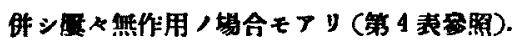

4) Neopirin

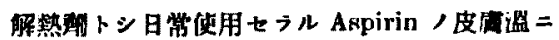

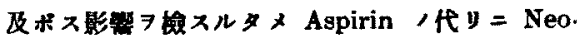
pirin (可溶性 Aspirin) 7 使用七y. Aspirin 一周

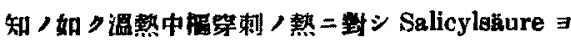
y著明ニ之す下降セシムルモノナリ，第 4 表二示

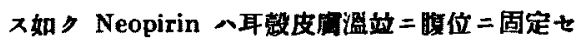

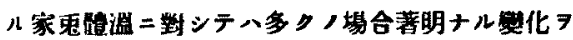

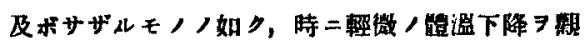
ルコトナリ.

策 5 表

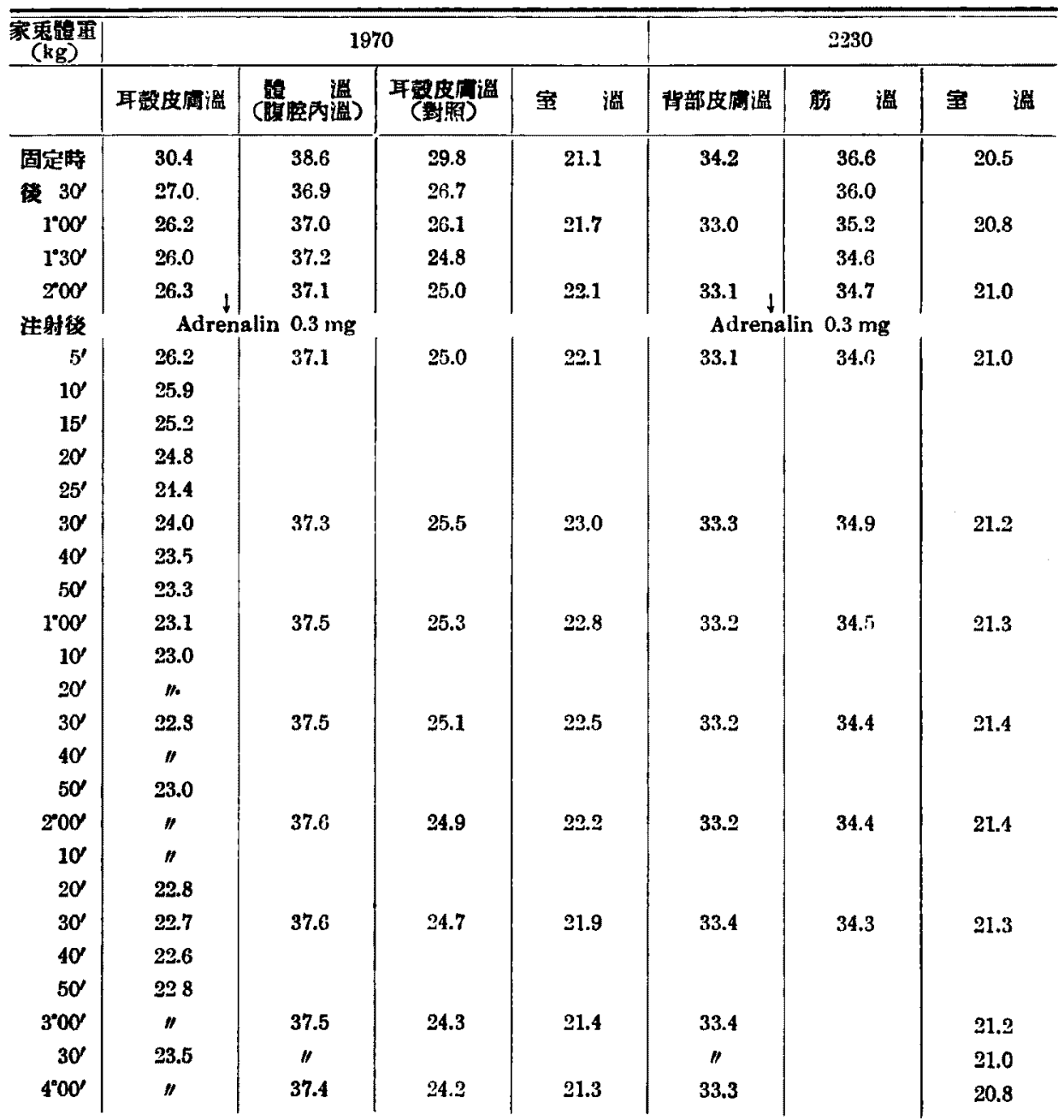




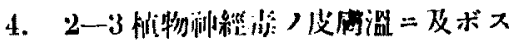
影謷

1) Adrenalin

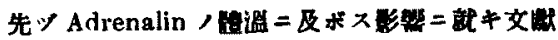

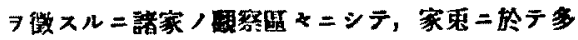
》/西 (Wolownik'15), Abderhalden u. Kan. tzech $^{1(i)}$, Epinger, Falta u. Radinger ${ }^{17)}$, Juschtschenko ${ }^{18}$, Hashimotods), Freund u. Grafe ${ }^{20}$ ) 八何レも AIrenalin，皮下注射 $=\Xi y$ 的谓 7 上.

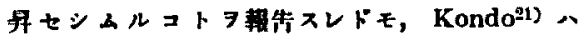

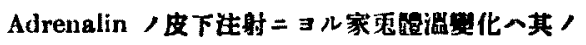
用量如何 Adrenalin / 皮下注射 =

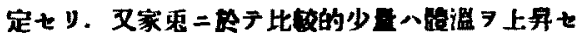

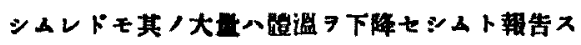
ル诸〉 y (Freund ${ }^{29)}$, Dobblin u. Fleischmann ${ }^{24)}$, Cloette u. Waser25)). 叉 Adrenalin /

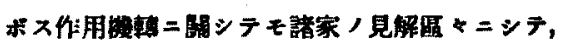
或者八中成性ナリトシ (Hashimoto, Cloette n. Waser, Kondo，间部)，或者ハ文末捎性ナyト スルモノナリ (Freund u. Grafe, Adler ${ }^{26)}$ ).

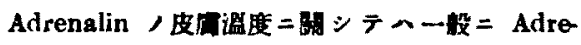
nalin 八末棺血管 7 收制セシムル 動ス儿血浓量八谈少スル

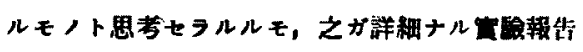

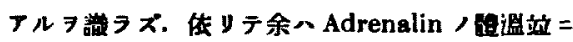

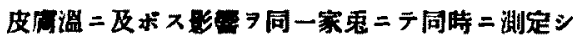

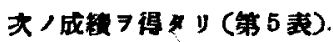

郎千第 5 表二示ス如”Adrenalin 八注射徙 10

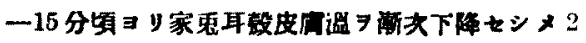
時間方至 2 時間釉ニシテ $2.5-3.5^{\circ} \mathrm{C} /$ 「降习示シ

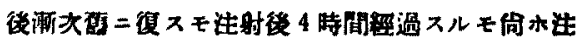

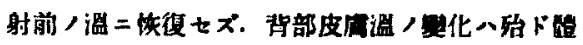

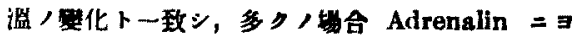

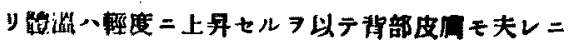

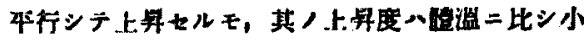

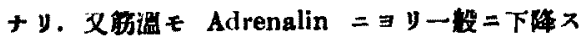

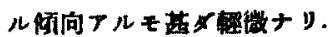

2) Atropin

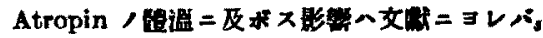
Meriot ${ }^{27)}$, Morat u. Doyon ${ }^{23)}$, Otto i. Collmar ${ }^{29)}$

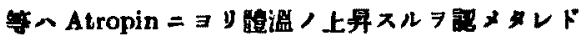

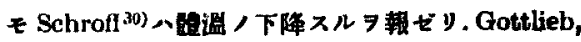
,Stiihlinger, Kiliaui 等 $=\Xi レ ハ$ Atropin 八家身

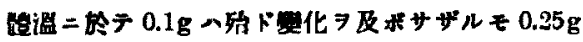

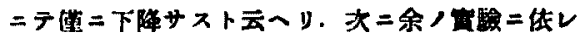

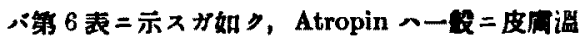

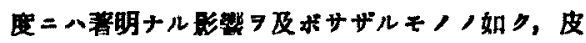

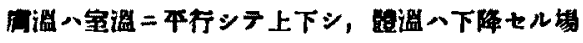

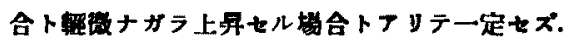

积 6 輩

\begin{tabular}{|c|c|c|c|c|}
\hline \multirow[t]{2}{*}{$\begin{array}{l}\text { (kg) } \\
\text { (kg) }\end{array}$} & \multicolumn{4}{|c|}{2190} \\
\hline & 耳策度溜 & (㫷 淄 & 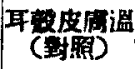 & 宝漫 \\
\hline 固定時 & 27.5 & 38.7 & 29.1 & 20.2 \\
\hline 徏 $30^{\circ}$ & 24.6 & 38.0 & 24.2 & \\
\hline 1000 & 22.2 & 37.2 & 22.6 & 20.3 \\
\hline $1^{*} 30^{\prime}$ & 22.4 & 36.3 & 21.9 & \\
\hline$r 00$ & 22.3 & 36.4 & 22.0 & 20.6 \\
\hline \multicolumn{5}{|c|}{ Atropin $5 \mathrm{mg}$} \\
\hline 10 & 22.4 & 36.4 & 22.0 & 20.6 \\
\hline $20^{\prime}$ & 22.5 & & 22.2 & \\
\hline $30^{\prime}$ & 22.8 & 36.5 & 22.5 & 21.0 \\
\hline $40^{\prime}$ & 23.0 & & 22.6 & \\
\hline $50^{\prime}$ & $"$ & & 22.5 & \\
\hline $1^{\circ} 00^{\prime}$ & 22.9 & 36.7 & 22.4 & 20.9 \\
\hline $10^{\prime}$ & $"$ & & & \\
\hline $20^{\prime}$ & 23.0 & & & \\
\hline $30^{\circ}$ & 23.1 & 96.7 & 22.6 & 21.2 \\
\hline $2^{\circ} 00^{\prime}$ & 23.0 & 36.5 & 22.4 & 21.0 \\
\hline $30^{\prime}$ & 22.6 & 36.4 & 22.0 & 20.5 \\
\hline 300 & 22.3 & 36.5 & 21.8 & 20.2 \\
\hline $30^{\prime}$ & 22.4 & 38.6 & 21.9 & 20.4 \\
\hline $1^{\circ} 00^{\prime}$ & 22.1 & 36.6 & 21.5 & 20.0 \\
\hline
\end{tabular}


3) Pilocarpin in = Acetylcholin

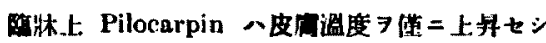

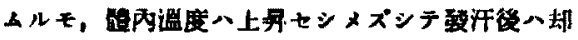

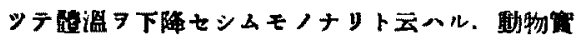
二於テ Pilocarpin ガ能滥

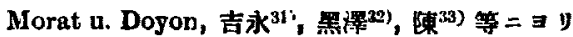

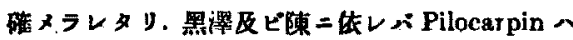

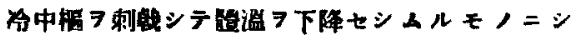
テ 0.1-0.3mg =テ注射令 $1-1.5$ 時間ニシテ0.4一 1.4 ${ }^{\circ} \mathrm{C}$ /下降 7 示スト. Acetylcholin モ Pilocarpinト同㧴喵滥

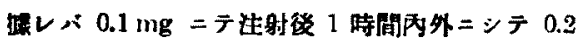

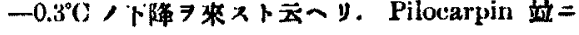

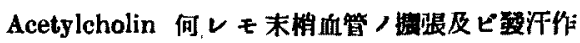

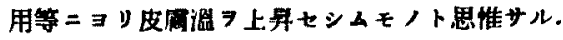

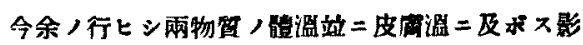

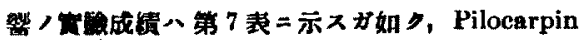

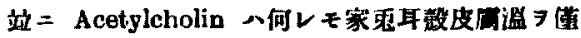
一上昇セシム㑔向アルモ每常現ルルモノニ非ズ.

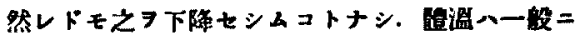
僅二下降セシ埸合多キモ又磨な無湖用ナルカ，時

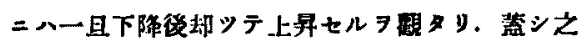

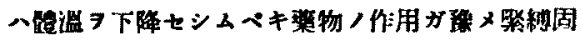

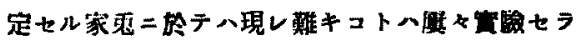
第 7 蔜

\begin{tabular}{|c|c|c|c|c|c|c|c|c|}
\hline \multirow[t]{3}{*}{ 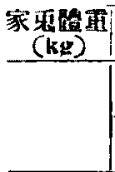 } & \multicolumn{4}{|c|}{ I 2310} & \multicolumn{4}{|c|}{ I 2150} \\
\hline & 耳 酸 & 皮而 温 & (是 & 队谓 & 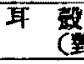 & 整 & 寄 & 温 \\
\hline & I & $\mathbf{I}$ & I & $\mathbf{I}$ & I & I & I & $\mathbf{I}$ \\
\hline 固定時 & 27.0 & 28.1 & 39.2 & 38.6 & 27.6 & 28.9 & 19.6 & 19.8 \\
\hline 级 $30^{\prime}$ & 23.2 & 23.5 & 37.5 & 37.2 & 23.8 & 24.2 & $"$ & $"$ \\
\hline$I^{\circ} 00$ & 22.7 & 23.0 & 35.9 & 37.3 & 22.9 & 23.8 & 19.7 & 20.0 \\
\hline $30^{\prime}$ & 22.5 & 22.7 & 37.1 & 37.4 & 29.4 & 23.6 & 19.8 & 20.1 \\
\hline $200^{\prime}$ & 22.4 & 22.5 & 36.9 & 37.0 & 22.5 & 23.5 & 20.0 & 20.3 \\
\hline 注璟㱛 & Pilocar & $0.1 \mathrm{mg} A$ & flehol. 1 & & & & & \\
\hline $10^{\prime}$ & 22.4 & 22.6 & 37.0 & 37.2 & 22.5 & 23.5 & 20.0 & 20.3 \\
\hline 20 & $"$ & 22.5 & & & & & & \\
\hline $30^{\prime}$ & 22.5 & 22.6 & 36.8 & 37.0 & 22.7 & 23.6 & 20.1 & 20.4 \\
\hline $40^{\prime}$ & $"$ & $"$ & & & & & & \\
\hline $50^{\prime}$ & 22.6 & $"$ & & & & & & \\
\hline $1^{\circ} 00^{\prime}$ & 22.5 & 22.8 & 36.7 & 36.8 & 22.8 & 23.7 & 20.2 & 20.5 \\
\hline $10^{\prime}$ & $" 1$ & 22.7 & & & & & & \\
\hline $2 \sigma^{\prime}$ & 22.7 & 22.8 & & & & & & \\
\hline $30^{\prime}$ & 22.6 & 22.7 & 36.7 & 36.7 & 22.7 & 23.6 & 20.2 & 20.4 \\
\hline $40^{\prime}$ & $" \prime$ & 22.8 & & & & & & \\
\hline $50^{\circ}$ & $n$ & $"$ & & & & & & \\
\hline 200 & 22.5 & 22.6 & 36.8 & 31.7 & 22.6 & 23.4 & 20.0 & 20.3 \\
\hline $30^{\prime}$ & 22.4 & 22.7 & & & & & & \\
\hline $30^{\prime} 00^{\prime}$ & $" \prime$ & 22.6 & 36.6 & 37.1 & 22.4 & 23.3 & 19.8 & 20.1 \\
\hline $30^{\prime}$ & 22.3 & 22.5 & & & & & & \\
\hline $4^{\circ} 00^{\prime}$ & 22.1 & 22.4 & 39.5 & 37.4 & 22.2 & 23.2 & 19.5 & 19.8 \\
\hline
\end{tabular}

家東 I - Pilocarpin $0.1 \mathrm{mg}$ 注射 家鬼 I - Acetylcholin $1 \mathrm{mg}$ 注射 


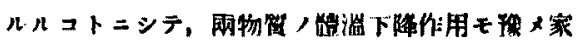

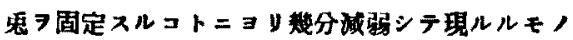
ナラン (第 7 姜里照).

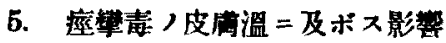

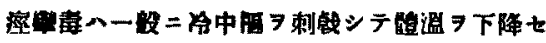

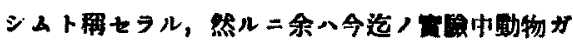

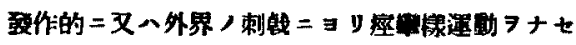

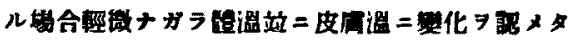

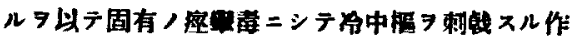

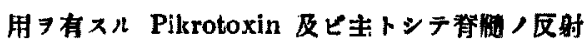

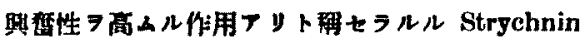

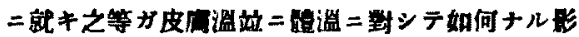

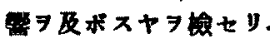

1) Pikrotoxin

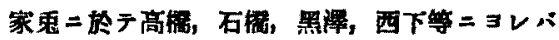

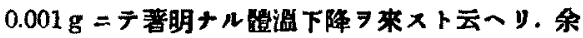

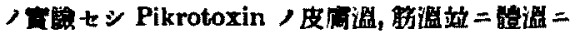

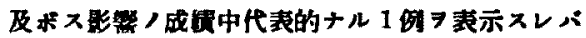

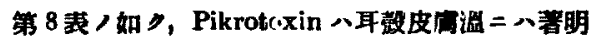
第 8 表

\begin{tabular}{|c|c|c|c|c|c|c|c|c|}
\hline \multirow[t]{2}{*}{ 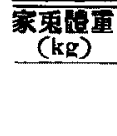 } & \multicolumn{4}{|c|}{2050} & \multicolumn{4}{|c|}{2110} \\
\hline & 耳教皮问盢 & 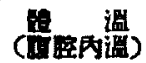 & 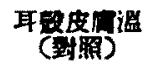 & 害 温 & 背部皮间盢 & 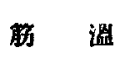 & 室 & 温 \\
\hline 固定時 & 26.5 & 39.3 & 28.3 & 19.5 & 35.7 & 37.0 & & 2.5 \\
\hline 锣 $30^{\prime}$ & 24.2 & 38.2 & 24.7 & & 34.7 & 35.8 & & \\
\hline $1^{\circ} 00^{\prime}$ & 23.1 & 37.8 & 23.3 & 19.8 & 34.2 & 35.1 & & 2.8 \\
\hline $30^{\prime}$ & 22.0 & 37.4 & 22.5 & & 34.0 & 35.2 & & \\
\hline $2^{\circ} 00$ & $22.0 \downarrow$ & 37.3 & 22.2 & 20.2 & $"$ & $"$ & & 3.4 \\
\hline
\end{tabular}

\begin{tabular}{|c|c|c|c|c|c|c|}
\hline $8+9+8$ & Pik & $5 \mathrm{mg}$ & & & Pik & $5 \mathrm{mg}$ \\
\hline 10 & 22.1 & 37.1 & 22.4 & 20.2 & 33.9 & 35.2 \\
\hline $20^{\circ}$ & $"$ & 36.8 & $" 1$ & & & \\
\hline $30^{\prime}$ & 22.2 & 36.7 & 22.6 & 20.3 & 33.5 & 35.0 \\
\hline $40^{\prime}$ & $"$ & & & & & \\
\hline $50^{\prime}$ & $"$ & & & & & \\
\hline $1^{\circ} 00^{\prime}$ & 22.3 & 36.3 & 22.7 & 20.5 & 33.1 & 34.6 \\
\hline $20^{\prime}$ & 22.4 & 36.2 & 11 & 20.6 & 33.2 & 34.3 \\
\hline$\left(24^{\prime}\right.$ & $"$ & 36.2 & & & & \\
\hline $25^{\prime}$ & 22.5 & 36.8 & & & & \\
\hline $26^{\prime}$ & 22.4 & 36.0 & & & & \\
\hline $40^{\prime}$ & 22.4 & 36.2 & 22.8 & 20.6 & 33.0 & 34.2 \\
\hline $200^{\prime}$ & 22.5 & $" \prime$ & 22.9 & 20.7 & 32.9 & 34.0 \\
\hline $16^{\prime}$ & 22.6 & 36.1 & & & & \\
\hline $17^{\prime}$ & 22.7 & 36.7 & & & & \\
\hline $18^{\prime}$ & "l & 35.9 & & & & \\
\hline $30^{\prime}$ & $"$ & 36.2 & 23.2 & 21.0 & & \\
\hline $3^{\circ} 00^{\prime}$ & 22.8 & 36.3 & 23.3 & 21.2 & 32.9 & 34.2 \\
\hline 30 & 22.5 & 36.2 & $\mathbf{2 3 . 0}$ & 20.8 & & \\
\hline $4^{\circ} 00^{\prime}$ & 22.3 & 36.3 & 22.6 & 20.5 & 33.3 & 34.7 \\
\hline
\end{tabular}

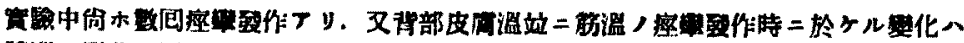

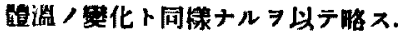

23.5

23.7

24.1

24.5

24.2

24.0 


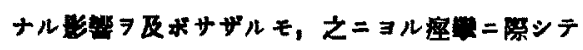

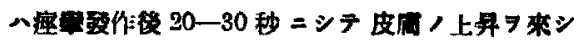

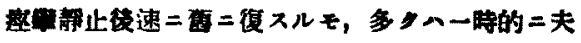

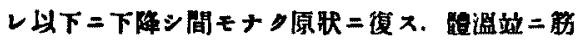
谓八Pikrotoxin $=\Xi$ 暗明二下降シ，背部皮㕅

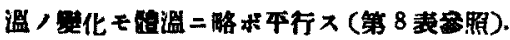

2) Strychnin

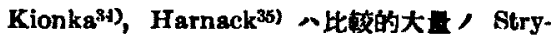

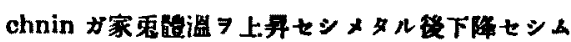

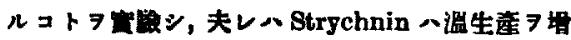

第

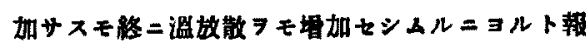

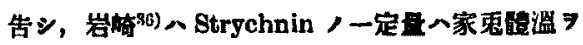

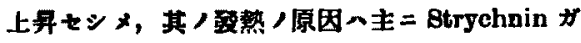

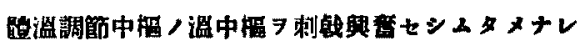

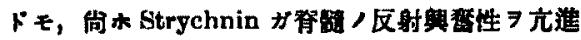

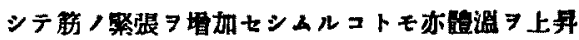
セシムル一因タルベシト謂一リ. 夷二余ノ Stry-

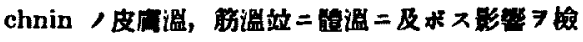
シタル成嘖，代表的ナル1何 7 示七く第 9 表，如

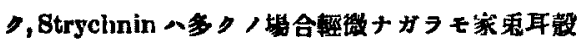
9 表

\begin{tabular}{|c|c|c|c|c|c|c|c|}
\hline \multirow[t]{2}{*}{$\begin{array}{c}\text { (kg) } \\
\end{array}$} & \multicolumn{4}{|c|}{2180} & \multicolumn{3}{|c|}{2230} \\
\hline & 耳酸友温 & 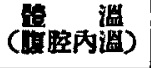 & $\begin{array}{c}\text { 耳永皮的谓 } \\
\text { (哩) }\end{array}$ & 害谓 & 草部皮解澼 & 骮娚 & 魮 \\
\hline 固定時 & 30.5 & 39.0 & 31.1 & 23.0 & 36.1 & 37.1 & 2.3 \\
\hline $30^{\prime}$ & 27.0 & 37.8 & 27.2 & & 35.6 & 36.4 & \\
\hline $1000^{\prime}$ & 25.5 & 37.3 & 36.1 & 23.2 & 35.4 & 35.9 & 22.6 \\
\hline $30^{\prime}$ & 24.9 & 36.9 & 25.3 & 29.4 & 33.8 & 35.5 & \\
\hline 200 & 25.0 & 4 & 25.4 & 23.6 & & 35.3 & 22.8 \\
\hline 注时管 & Strych & nin $0.3 \mathrm{mg}$ & & & Strycl & $\operatorname{lin} 0.3 \mathrm{mg}$ & \\
\hline $10^{\prime}$ & 25.1 & 36.9 & 25.5 & 23.7 & 33.9 & 35.4 & \\
\hline $20^{\prime}$ & 25.2 & 37.0 & 25.6 & & & & \\
\hline $30^{\prime}$ & 25.3 & 37.1 & 25.8 & 24.0 & 34.0 & 35.6 & 23.3 \\
\hline $40^{\prime}$ & 25.4 & $"$ & 26.0 & 24.2 & & & \\
\hline$\left(46^{\prime}\right.$ & 25.4 & $"$ & & & & & \\
\hline 47 & 25.5 & 37.3 & & & & & \\
\hline $48^{\prime}$ & 25.8 & 38.0 & & & & & \\
\hline 149 & 26.0 & 36.8 & & & & & \\
\hline $50^{\circ}$ & 25.9 & 37.2 & 26.4 & & & & \\
\hline $1^{\circ} 00^{\prime}$ & $n$ & $" \prime$ & 36.5 & 24.6 & 34.1 & 36.2 & 24.1 \\
\hline $30^{\prime}$ & 26.0 & 37.4 & $21: .9$ & 25.0 & 34.4 & 36.8 & 24.5 \\
\hline 座 $34^{\prime}$ & 26.0 & $\|$ & & & & & \\
\hline $35^{\prime}$ & 26.2 & 38.0 & & & & & \\
\hline $36^{\prime}$ & 26.1 & 37.1 & & & & & \\
\hline 200 & $\|$ & 37.5 & 27.1 & 25.3 & 34.6 & 36.7 & 24.8 \\
\hline $30^{\prime}$ & 26.0 & 37.6 & 27.2 & 25.5 & $" \prime$ & 36.5 & 24.5 \\
\hline $3^{\circ} 00^{\prime}$ & 25.7 & 37.8 & 26.5 & 24.8 & 34.8 & 36.3 & 24.3 \\
\hline $30^{\prime}$ & 25.5 & 37.6 & 26.3 & 24.6 & 34.5 & 36.0 & 24.1 \\
\hline $4^{\circ} 00^{\prime}$ & 26.4 & $\|$ & 26.0 & 24.4 & $" l$ & 35.8 & 23.9 \\
\hline
\end{tabular}

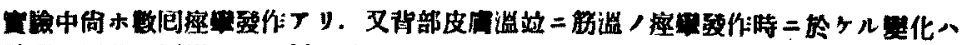

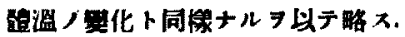


皮咸温

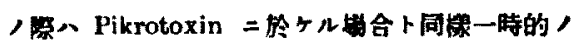
上其习明儿、第 9 表二於テ Strychnin 7 法期セル

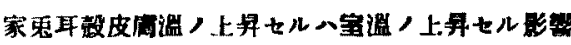

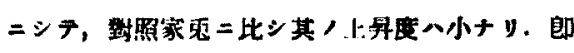

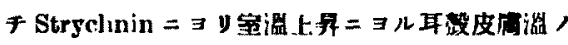
上年ガ或程度甽制セラレタルモノニシテ，空调ノ

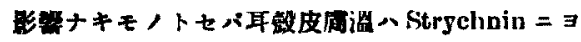

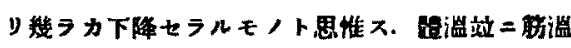

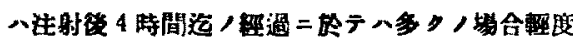

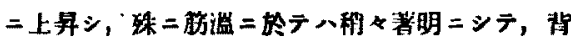

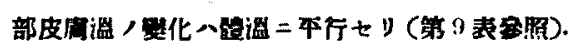

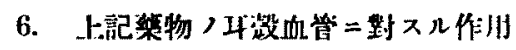

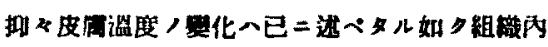

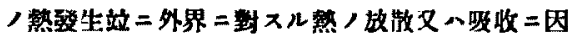

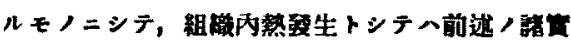

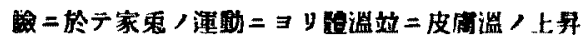

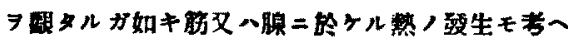

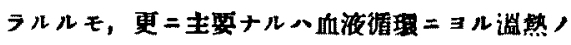

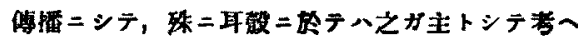

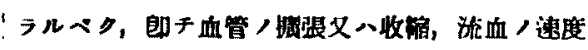
如问等二因ルコトオナラント思考ス. 估リテ之等

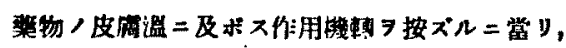
主要ナル役慧

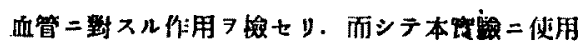

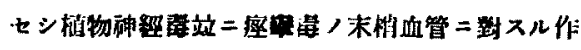
用ハー货二周知ナル

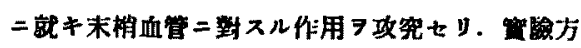
法トシテハ家臣耳教血管用ヒテ Kruwkow ${ }^{37)}$.

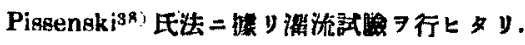

1) Antipyrin

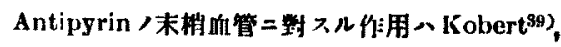

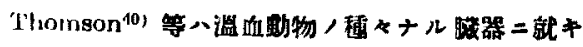

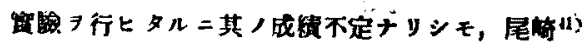

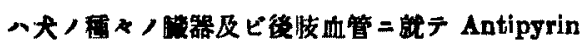

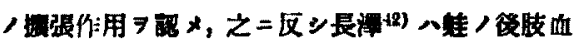

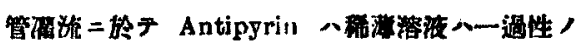

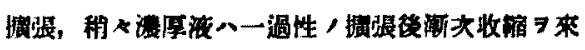

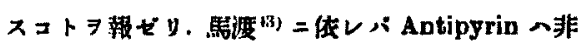

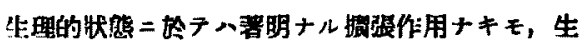

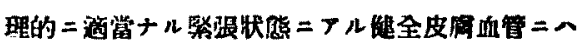

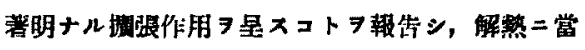
y Antipyrin 八中保作用以外二局所作用乇亦相

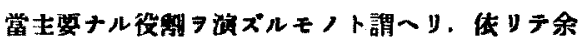

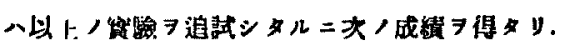

a. Ringer 液 $=$ テ溜湤セル血管二對スル Antipyrin , fi:用

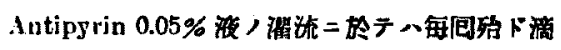

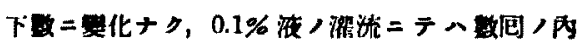

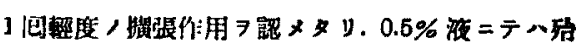

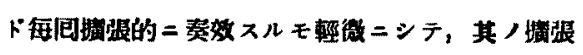

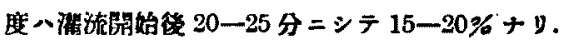

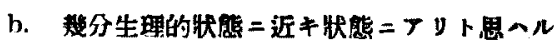
ル血管二竕スル Antipgrin，作用

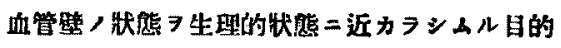

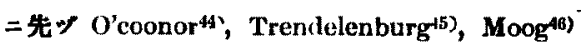

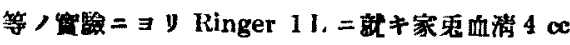

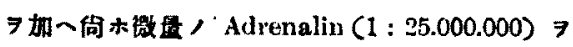

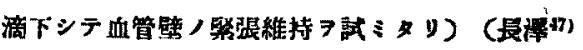

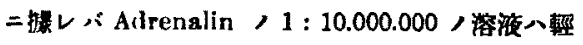

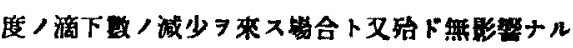
場合トアリト)，蓋シ血清ハ夫レ自身 Adrenalin

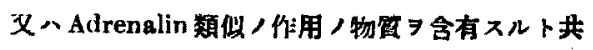
= Adrenalin ト／共存二嘗y「「ルカリ性」ナル Ringer 液中二於テモAdrenalin，分解 7 阻此 ル能カョ有スレバナリ. 例人血清ノミニテハ努果 ナキ域合ニモ之二Adrenalin，插り徼量 $\ni$ 加 フ

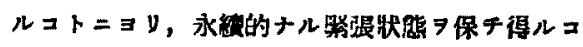

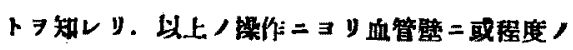




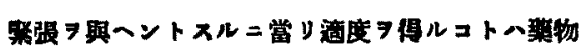

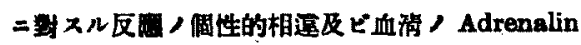

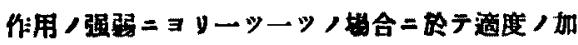

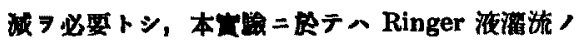

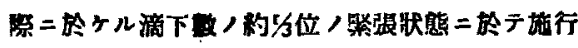
七り. 斯カ几狀照

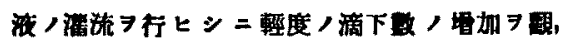

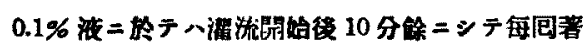

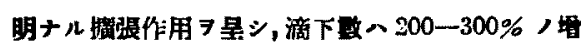

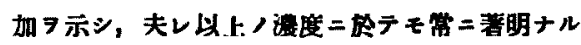

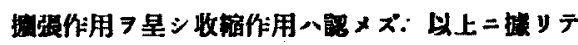

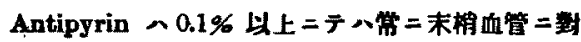

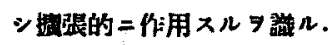

2) Chininum hydrochloricum

Chinin，血管作用二箖シテハKobert $\mathrm{u}$

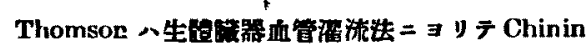

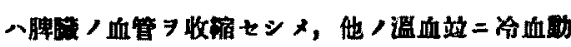

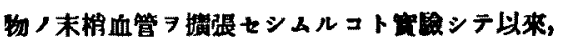

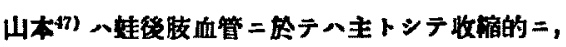

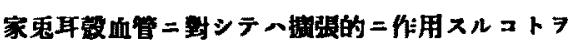

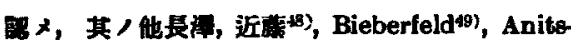

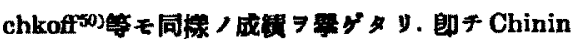

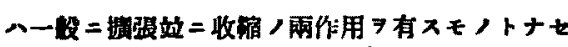
几ガ如シ. 体りテ余モ办 Chinin／家种耳䓵血管

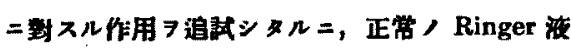

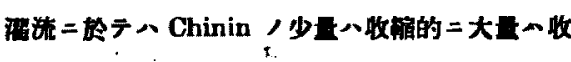

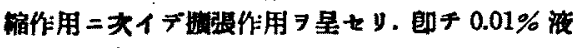

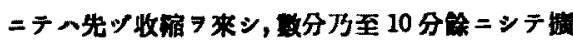
嵹作用 7 的

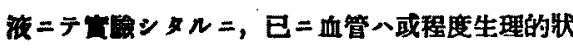

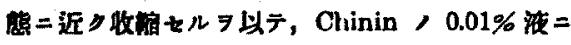

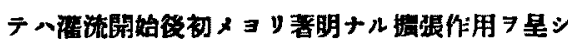

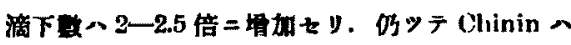
Adrenalin-血清 $=ヨ y$ 生理的状留二近カラシメ

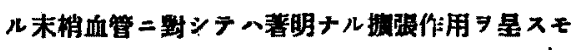

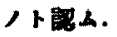

3) Natrium Balicylicum

Natrium salicylicum，血管二及代 ス作用=就

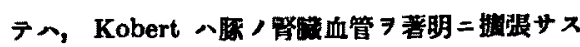

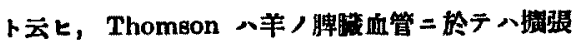
ヨ示をドモ，蛙／後肢血管二於テ八笨明ナル血管

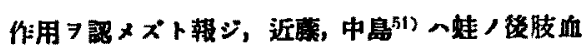
管二丵シ瀑度小ナル時八血管

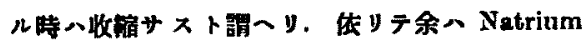
salicylicum，家鬼耳款血管二到スル作用 7 检

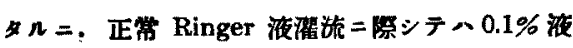

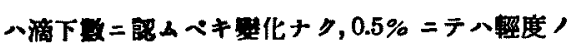

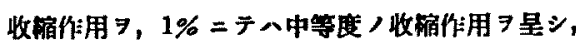

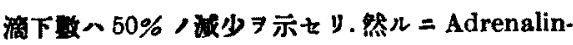

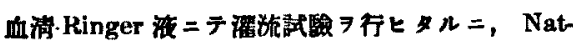

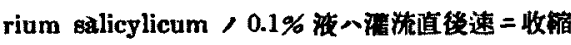

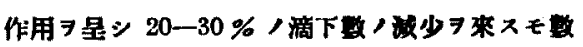

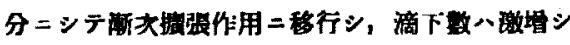

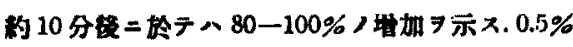

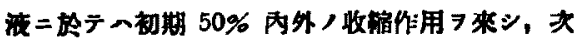

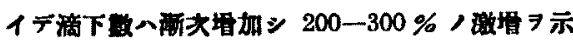

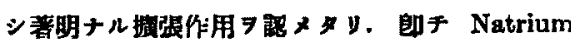
salicylicum 八Adrenalin-血清-Ringer 液燿流=

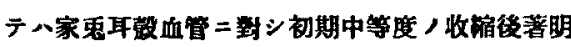

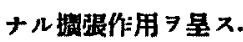

4) Neopirin

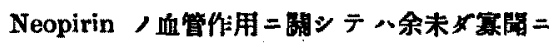

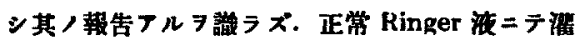
流 $\ni$ 行

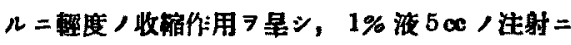

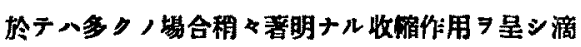

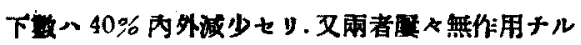
场合モ 7 リ. 然ル = Adrenalin-血清-Ringer 源,

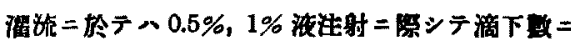

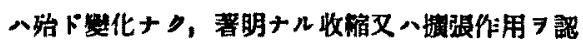
ムルコト能ハメ゙. 


\section{教察}

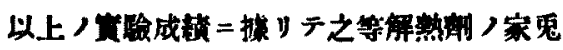
耳墪血管二對スル作用八明カトナレルモ，之 等 ノ作用八唯末梢血管二斯スル作用ノミナル

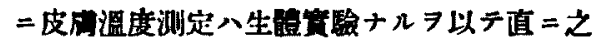
等 〉關俰 7 断言シ嚾キモ, Antipyrin, Chinin,

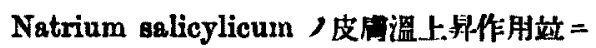
Adrenalin, Strychnin，皮学溫下降作用八 之等篗物血管作用ト一致ス几點厂几ラ以テ少 クトモ一部末梢血管/摸张及一收㜚作用二 因スルモノト推定スルラ得ベシ. 然レドモ Pilocarpin, Acetylcholin /如丰血管掅㖘作 用习有ス几物算二於テモ上遮／解熱風，如キ

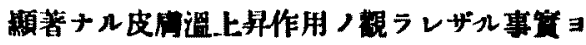

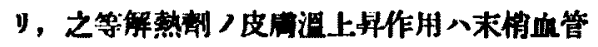
据镸作用以外 =中框性血管作用モ與ス几モ ノナルベク，及 Pilocarpin 及とAcetylcholin

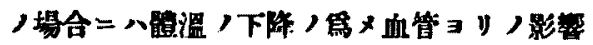

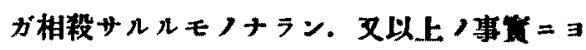
y Antipyrin, Chinin, Natrium salicylicum

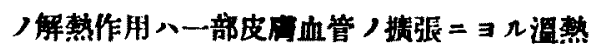

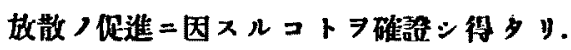

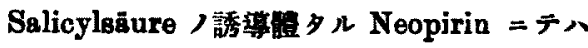

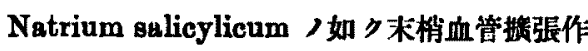
用八認メザルモ，其ノ Nat. salicylium =卓 越七几解熱作用、A Apirin ト同栐分解セラレ タル Salicyleäure =非ズシテ原形ノ售吸收 セラレタル分子ノ作用二因スルモノト挎へラ ル. 山本 ${ }^{i 2)}$ E Aspirin IN Natrium salicylioum

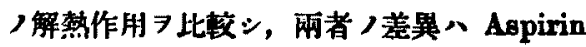
分子ガ Salieylsiñe 分子二卓越七几谓熱中

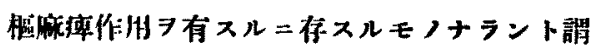
ヘリ. メ以上余，萲驗二借七シ解熱剂=於テ

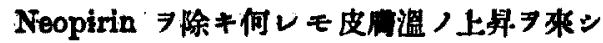

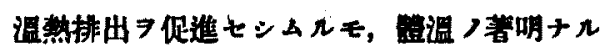

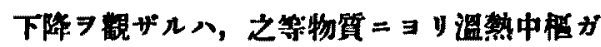

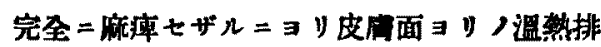
H) 促進二伴七テ触內溫热生産モ亦倠進七ラ ルモノト想像ス。

以上諸签驗 7 要約スレペ,

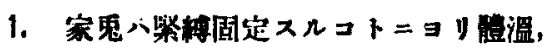
觔溫立二皮间溫八何レモ下降シ 1.5一2時間

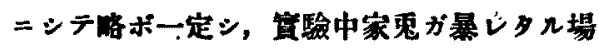
合八一時的二之等调度八上年

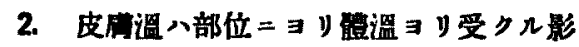
整二著美アリ，背部皮间谓八腹腔內二於テ测 定セラレタル福渭 影繁习受クルコト大ナル

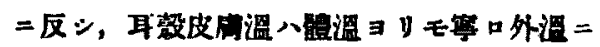

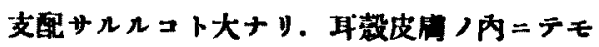

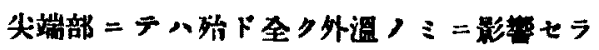

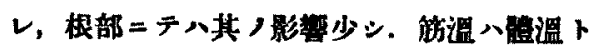
最モ近シ。

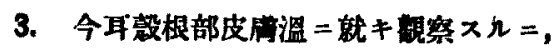

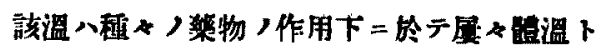
相反スル轻過引取ルコトフリ. Antipyrin, Chinin, Natrium salicylicum ハ务ク 場合 之ヨ上年セシメ，殊=Antipyrin =於テ最モ

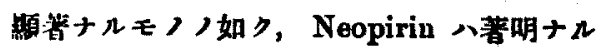

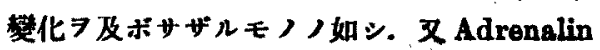
八之ヨ下降セシメ、Atropin 八之二對レ㱠ド 热作用ニシテ, Pilocarpin, Acetylcholin へ

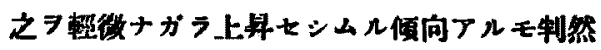

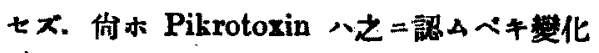
ヨ及ボサザルモ Pikrotorin 座极中其， 


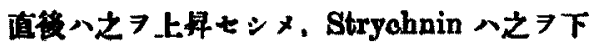
降セシムルガ如キモ頑著ナラス， Stryohnin

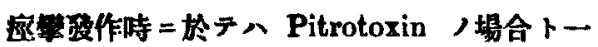
教 $x$.

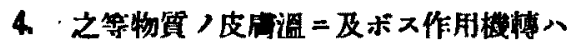

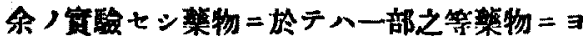

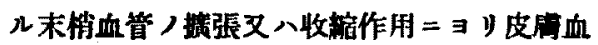

管习流レル血液量 坦加又八減少=因スルモ

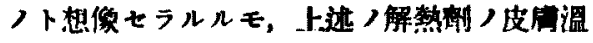

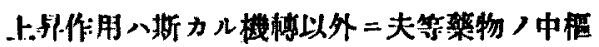
性血管作用モ大イ=開與スべク，又何レノ整

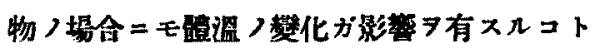

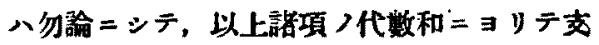
配サルルモノト考へラル。

\section{文}

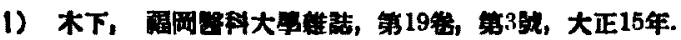

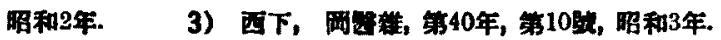

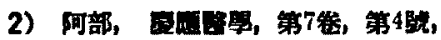
Pharm., Bd. 26, 8. 419, 1890 und Bd. 28, 8. 170, 1891.

4) Gouttieb, Arch. t. exp. Path. u. Pharm., Bd. 43, S. 166, 1899 . 6) Kitiani, Arch. intern. de Pharm. et de Therap., Vol. 20, p. 333, 1910.7 7) Laache, Centralbral. f. Klin. Med., Bd. 7, S. 545, $1886 . \quad$ 8) Grasu, Deutsche Med. Wochenschr., Nr. $3,1899 . \quad$ 9) Fröhwer, Monathefte $f$. prak. Tierheilkunde, Bd. 5, 8. 399, 1884. 10) Liepelt, Arch. f. exp. Path. u. Pharm., Bd. 43, S. 154, $1900 . \quad$ (1)

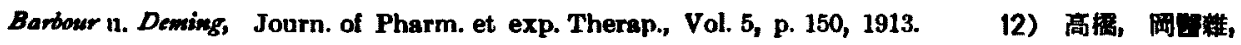

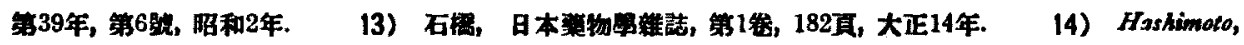
Arch. f. exp. Path. u. Pharm., Bd. 78, 8. 370, $1915 . \quad$ 15) Wolownik, Arch. f. pathol. Anat, Bd. 180, S. 255, 1905.1 16) Abderhalden (1. Kantsseh, Zeitschr. f. physiol. Chemie, Bd. 61, 8. 119, 1909. 17) Epinger, Falta 1. Rndinger, Zeitschr. f. klin. Med., Bd. 61, 8. 1, 1908. 18) Juscheschemko, Biochem. Zeitsehr., Bd. 15, B. 365, 1912 19) Hashimoto, Arch. f. exp. Path. u. Pharm., Bd. 78, 8. 394, $1915 . \quad$ 20) Freund u. Gmfe, Arch. f. exp. Path. u. Pharm., Bd. 67, 8. 55, 1912 21) Kondo, Acta Schol. med. Kioto., Bd. 3, S. 169, 1919. 22) Rieser, Arch. t. exp. Path. D. Pharm., Bd. 80, 8. 183, 1917. 23) Areund, Arch. I. exp. Path. u. Pharm., Bd. 65, 8. 255, $1911 . \quad$ 24) Döbin u. Fleischenawn, Zeitschr. \&. klin. Med., Bd. 78, B. 275, 1913. 25) Cloette u. Waser, Arch. f. exp. Path. u. Pharm., Bd. 7 , S. 30, 1916. 26) Adler, Arch. f. exp. Path. u. Pharm., Bd. 27, S. 409,1890 und Bd. 86, S. 159, 1920. 27) Meriat, These de Parig, 1868 . 28) Morat u. Dayon, Compt. rend. de la soc. de Biol., 633, 1892. 29) Otto u. Collmar, Thrapeut. Gazette, 511, 1887. 30) Schroff, Zeitschr. d. ges.

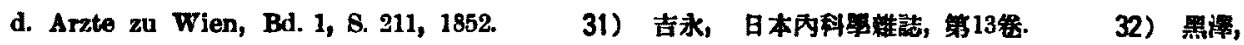

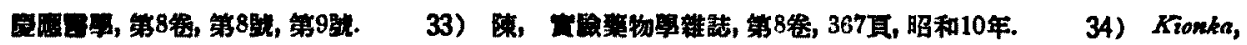
Arch. internat. Pharmakodyn., Vol. 5, p. 111, $1898 . \quad 35)$ Barnack, Arch. f. exp. Path. u.

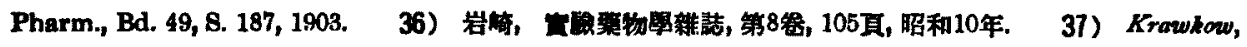
Zeitschr. f. d. gen. exp. Med., Bd. 27, 8. 127, 1922, Bd. 34, 8. 279, 1923. 38) Pissemski, PAliger's Arch., Bd. 156, B. 426, 1914. 39) Kobert, Arch. f. exp. Path. a. Pharm., Bd. 22, 8. 77, 1887. 
40) Thomson, Utber die Beeinfluss d. pripheren Gefksse durch pharm. Agentien, 1886. 41) 狌崎,

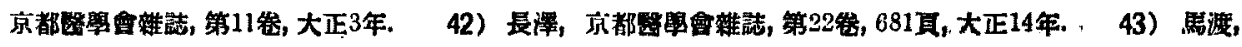

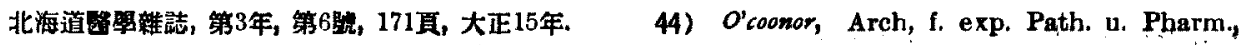
Bd. 67, S. 195, 1912.45$)$ Trendelenburg, Münchener Med., Bd. 36, S. 1911.46 ) Mitoog,

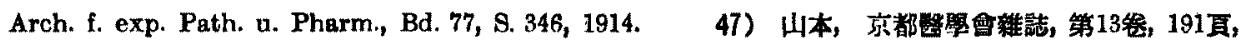

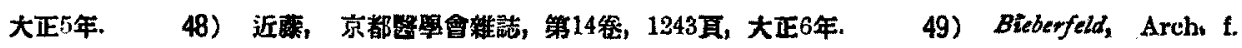
exp. Path. u. Pharm., Bd. 79, S. 361, 1916. 50) Anitschkoff, Russki Phyeiolagitscheski Jurnal imeni Ssetschenowa, Bd. 2, S. 206, 1912, Ref. in Berichte über die gesamt Phỵsiolog., Bd. 15,

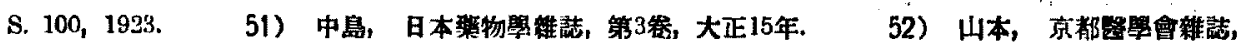
第15\%然，283貣，大正7年. 